Bojanić Rašović, M. (2021): The most important methods of disinfection in beekeeping. Agriculture and Forestry, 67 (3): 167-176

DOI: 10.17707/AgricultForest.67.3.14

Mirjana BOJANIĆ RAŠOVIĆl

\title{
THE MOST IMPORTANT METHODS OF DISINFECTION IN BEEKEEPING
}

\section{SUMMARY}

The hygiene of beehives is of the utmost importance for the protection of the health of bees and bee products. Disinfection is a very important hygienic measure that is carried out in order to prevent and suppress infectious diseases of bees and contamination of honey and other bee products with harmful microorganisms. The disinfection procedure is very complex, and its efficiency depends on a large number of factors. In beekeeping, as well as in other branches of animal husbandry, preventive, liquid and final disinfection is carried out. During the disinfection, the following factors must be taken into account: the spectrum of action of the disinfectant, the method of application, the concentration of the disinfectant, the exposure time, the properties of the environment to be disinfected. The active substances of disinfectants usually affect the metabolism of microorganisms. For disinfection in beekeeping can be used: chlorine preparations, iodine preparations, bases, acids, quaternary ammonium compounds, aldehydes (glutaraldehyde, glyoxal), oxidizing agents (hydrogen peroxide, acetic acid). There is no ideal disinfectant. Due to the toxicity and other harmful effects of disinfectants, and often their insufficient efficiency, preference should be given to physical methods of disinfection, whenever possible. Chemical disinfection is often not successful, especially when it comes to the causative agents of American bee brood plague, which form very resistant spores. In that case, the only way is to burn the hives, so that they are not a source of infection. Against the spores of Paenibacillus larvae, the most effective chemical disinfectants are chlorine preparations, warm solution of sodium hydroxide, oxidizing agents, therefore, these disinfectants are most often used in beekeeping. However, the negative properties of these disinfectants should also be taken into account. larvae

Key words: beekeeping, hygiene, disinfection, spores, Paenibacillus

\section{INTRODUCTION}

Hygiene is of the greatest importance for the protection of the health of bees and bee products. That is why disinfection in beekeeping is being paid more

\footnotetext{
${ }^{1}$ Mirjana Bojanić Rašović (corresponding author: bojanic.m@t-com.me) Biotechnical Faculty, Podgorica,University of Montenegroe, MONTENEGRO

Notes: The author declares that she has no conflicts of interest. Authorship Form signed online. 
and more attention. The process of disinfection destroys microorganisms by physical, chemical or combined procedures in order to stop the spread of infection from its source to the susceptible organism. Disinfection can be defined as the destruction or killing of microorganisms on objects, in water, in the air and on undamaged skin up to the number that will not be able to cause disease or spoilage of food. Sterilization, unlike disinfection, involves killing all microorganisms, both their vegetative and sporogenic forms. The term disinfectants mean chemical agents that are used to destroy microorganisms on surfaces, objects, utensils and other inanimate matter (Bojanić Rašović et al. 2016; Bojanić Rašović 2018a; 2019a; 2019b; 2019c; 2021a, 2021b, 2021c, 2021d).

\section{Disinfection in beekeeping}

\section{MATERIAL AND METHODS}

Types of disinfection in beekeeping

When considering a particular epidemiological situation, the following types of disinfection are distinguished: preventive, focal and final. Preventive disinfection is performed before an infectious disease appears in the apiary. This disinfection aims to prevent the occurrence of infectious diseases of bees. Preventive disinfection is carried out with disinfectants with a wide spectrum of action - agents that act on the largest number of microorganisms. It aims to reduce the number of all microorganisms that can be found in the apiary and that can lead to infectious diseases. Focal disinfection aims to kill the pathogen at the site of the outbreak and stop its further spread. It is carried out for the duration of the disease and is directed at the microorganism that led to the infectious disease. Final disinfection is carried out after the cessation of the disease, i.e when two incubation periods have passed since the appearance of the last symptoms of the disease. The goal of final disinfection is to destroy all remaining infectious agents that have not been destroyed by focal disinfection. It is carried out with the same means and the same concentration as the focal disinfection (Radenkovic Damnjanović, 2010, Bojanić Rašović, 2021b). Only approved preparations and procedures may be used for disinfection. During disinfection, the following must be taken into account: source, route, mode of spread of infectious disease, properties of microorganisms against which disinfection is performed, spectrum of action and other properties of disinfectant, method of application and required disinfectant concentration, exposure time, disinfecting environment, etc. It should also be borne in mind that the two disinfectants may have an inhibitory or potentiating effect (synergy) (Asaj, 2000, Vučemilo, 2008, Titera 2009).

Physical methods of disinfection

Physical methods of disinfection are mainly based on the use of dry or wet heat and the application of radiation. Incineration is the oldest and very good method of physical disinfection. This kills very resistant bacteria (such as the causative agent of the American bee brood plague). Burning is a procedure that involves exposing contaminated objects to flames, in order to destroy the 
pathogens that are on them. In this way, metal objects as well as some wooden objects can be disinfected. The effect of disinfecting hot water under normal atmospheric pressure for 30 minutes is increased by adding 1-2\% crystalline soda $\left(\mathrm{Na}_{2} \mathrm{CO}_{3}\right.$, sodium carbonate). Disinfection with hot water steam created by fixed or mobile steam generators is also a successful method of disinfection. Unlike water, water vapor can have temperatures higher than $100^{\circ} \mathrm{C}$. In order for disinfection to be effective, water vapor must be under a certain pressure and at a minimum temperature of $110^{\circ} \mathrm{C}$ for $40-45$ minutes. Dry hot air flowing, temperatures from $110^{\circ} \mathrm{C}$ to $150^{\circ} \mathrm{C}$ in ovens and dryers for 30 minutes are also used for disinfection (Bojanić Rašović, 2021a). Ultraviolet radiation with a wavelength of $253-280 \mathrm{~nm}$ has a bactericidal effect. Maximum efficiency is achieved with rays of wavelength $265 \mathrm{~nm}$. Sources of UV radiation, in addition to the sun, are various fluorescent lamps. Ultraviolet radiation cannot penetrate inside the objects being treated - the radiation only acts on the surface being irradiated. Sporulating bacteria are resistant to ultraviolet radiation (Belojević, 2013, Titera 2009).

Chemical methods of disinfection

Disinfectants represent a diverse group of chemical substances that create unfavorable conditions for the survival of microorganisms. Microbicides (bactericides, fungicides, virucides, sporocides) kill microorganisms or their spores, while microbistatics (bacteriostatics, fungistatics) only stop the growth of microorganisms. The active substances of disinfectants usually affect the metabolism of microorganisms (Buchrieser and Miorini, 2009). Chemical reactions on which the action of disinfectants is most often based are: oxidation (chlorine and chlorine preparations - hypochlorites, chloramines, isocyanurates, iodine and iodine preparations - iodophores, hydrogen peroxide, other peroxide compounds, ozone, ethylene oxide), hydrolysis (acids, caustic soda, hot water), formation of protein salts (alkali metal and heavy metal salts), coagulation of proteins in microorganism cells (quaternary ammonium salts, metals, phenols, alcohols), changes in cell membrane permeability, mechanical damage to microorganism cells (quaternary ammonium salts), penetration into the enzyme system of microorganisms (metals, formaldehyde, phenols). Chemical methods of disinfection dominate over the physical methods in many ways. During the disinfection, it is necessary to carry out preliminary disinfection, which are mechanical cleaning and sanitary washing, and then the disinfection itself. Sometimes both phases can be performed using detergents and disinfectants. The effects of disinfection also depend on the way in which the disinfectant is applied to the places where microorganisms need to be destroyed. Disinfection of surfaces and objects can be done by immersion in disinfectant, wiping with a cloth soaked in disinfectant, spraying, releasing gas, evaporation of disinfectant. When performing disinfection, the contractor must have a protective suit, hat, gloves, boots, goggles and respirator, a handy pharmacy with appropriate antidotes (Vukićević and Hrgović, 1988, Asaj, 2000). The disinfectant solution should be prepared immediately before use, as its effectiveness declines over 
time. Increased efficiency of some preparations can be achieved by higher temperature of the solution. For chlorine compounds, phenols and quaternary ammonium salts, the solution should be heated to 50 to $60^{\circ} \mathrm{C}$, and for hydroxides to $80^{\circ} \mathrm{C}$. It is very good to change disinfectants periodically, to prevent the formation of resistance of microorganisms to any of the active disinfectant substances.

\section{RESULTS AND DISCUSSION}

Types of chemical substances with disinfectant properties

The mechanism of action of halogen is based on a combination of the action of highly reactive halogen compounds and oxygen released in an alkaline environment. Sodium hypochlorite $(\mathrm{NaClO})$ has a very good bactericidal and virucidal effect. Its use is wide. It is an effective ingredient in many commercial preparations. Commercially available preparations generally contain about 5\% sodium hypochlorite (bleach), which are diluted according to the instructions. It needs to act for approximately 30 minutes to achieve a disinfectant effect (Titera, 2009). The hives are disinfected with a warm $0.5 \%$ hypochlorite solution for 20 minutes (Anon, 2014). Caution should be exercised when mixing sodium hypochlorite with acids and acidic disinfectants, as it releases hydrogen chloride gas which, when inhaled, has an irritating and toxic effect on humans. Chlorinated lime - calcium hypochlorite should contain at least $25 \%$ active chlorine. Solutions of bases and alkaline salts act on the basis of a high concentration of hydroxyl anions (OH-). Solutions with a $\mathrm{pH}$ greater than 12 are very effective. They can be used while they are hot, but then needs to be more careful. Caustic soda $(\mathrm{NaOH})$ burns are very deep. Caustic soda solutions dissolve beeswax and fat, so they are widely used in beekeeping. They are easily available and relatively cheap. This group includes potassium hydroxide $(\mathrm{KOH})$, sodium hydroxide (caustic soda, $\mathrm{NaOH}$ ), calcium hydroxide (slaked lime, $\mathrm{Ca}$ $(\mathrm{OH})_{2}$ - used in a concentration of 10 to $20 \%$ for disinfection of soil, waste storage, etc.), sodium carbonate. Sodium carbonate (soda, $\mathrm{Na}_{2} \mathrm{CO}_{3}$ ) is used in a concentration of 2 to $6 \%$, preferably as hot solutions (they destroy the spores of the causative agent of American bee brood at $80^{\circ} \mathrm{C}$ ). Caustic soda is used to disinfect hives in a concentration of $2-4 \%$ (Periškić et al. 2013). Inorganic acids are relatively effective, but they are also caustic - they corrode materials. They act as aqueous solutions based on a high concentration of reactive hydrogen ions. They are not often used in beekeeping. Hydrochloric acid at a concentration of $10 \%(\mathrm{HCl})$ is used for general cleaning. Phosphoric $\left(\mathrm{H}_{3} \mathrm{PO}_{4}\right)$ and sulfuric acid $\left(\mathrm{H}_{2} \mathrm{SO}_{4}\right)$ in concentrations of 0.5 to $5 \%$ are used in beeswax processing. Organic acids, formic and oxalic are mostly used in beekeeping against the parasitic mite Varroa destructor. They also have a disinfecting effect against some bacteria and fungi (the cause of stone bee litter, lime bee litter and bee nosemosis). They are most often used in the form of steam (Anon, 2014). Peracetic acid (also known as peroxyacetic acid is a good agent for cleaning and disinfecting glassware. It is used in concentrations of $0.2-0.5 \%$, where the treatment should last at least 10 minutes For disinfection in beekeeping practices can be used oxidizing substances. Hydrogen peroxide $\left(\mathrm{H}_{2} \mathrm{O}_{2}\right)$ is stored as an aqueous solution. It is sold 
as a $3 \%, 10 \%$ as well as a $30 \%$ solution. Solutions of 0.5 to $3 \%$ concentration are most often used for disinfection. Organic peroxides are modern, but expensive disinfectants. They work against the spores of the bacterium that causes the American bee brood plague (Paenibacillus larvae). Their advantage is that they are environmentally friendly because they decompose into harmless substances (Asaj, 2000, Titera, 2009). Some metals have a very toxic effect on living cells of microorganisms. Silver compounds are used for disinfection of drinking water. Bees tolerate colloidal silver, nanosilver and copper relatively well. Many commercial disinfectants are based on alcohols (ethanol, isopropyl alcohol and others). They have the best effect in aqueous solutions in a concentration of about $70 \%$ and in combination with other active substances. Concentrated alcohol (pure alcohol, 99\%), as well as too dilute alcohol (eg concentrations of alcohol in rum, whiskey, plum brandy) do not have a good disinfectant effect. Alcoholic preparations are not enough to destroy the spores of microorganisms, nor the spores of the causative agent of the American bee brood plague. They are effective against some viruses that have a lipid envelope. The disinfecting effect of aldehydes is based on reduction reactions, as well as on their reaction with cell proteins of microorganisms, whereby protein denaturation occurs. Formaldehyde $(\mathrm{HCHO})$ is a gas. An aqueous solution with a concentration of 35 to $40 \%$ is known as formalin. Very strict rules regulate its use, because it has a detrimental effect on human health (potential carcinogen). A 1-5\% formalin solution is used to disinfect the surface (Anon, 2019). Porous objects such as wood and wax frames must not be disinfected with formaldehyde, as its residues cannot be removed after treatment. This dangerous substance must not come into contact with food and bee products (Žarković, 1971). Glutaraldehyde is the basis of very effective disinfectants. After prolonged exposure, it safely destroys bacteria, viruses and spores of microorganisms. It is used as part of mixed disinfectants. Before use, it is diluted in a concentration of $2 \%$ and alkalized by the addition of $0.3 \% \mathrm{NaHCO}_{3}$ (sodium bicarbonate). Cyclic compounds are group of substances that damage the enzymes and cell protoplasm of microorganisms. They irritate the skin and have a characteristic odor. Therefore, despite their effectiveness, they are not used in beekeeping. Some, like phenol, are carcinogenic. Detergents are complex in composition and can contain more than 25 different ingredients. Surfactants are the most important ingredients in detergents and are found in all types of detergents. Surfactants are substances that lower the surface tension of a liquid (water). Soaps are anionic surfactants, which are used for washing and cleaning, giving a surface-active anion in aqueous solution. The primary function of soap is to regulate the foam in laundry detergents, as it gives the greatest volume. Anionic surfactants make up $70-75 \%$ of the total surfactant consumption in the world. Quaternary ammonium compounds (benzalkonium chloride, cetrimonium chloride, etc. - commercial preparation Asepsol, 5\% benzalkonium chloride solution) are cationic surfactants that act on gram positive bacteria - do not act on gram negative bacteria. Amphoteric surfactants (amphotensides) (lauryl diethylene diamino glycine - commercial preparation $\mathrm{DeSu}$ ) - anionic groups are carriers of detergent and cationic carriers of bactericidal properties. The mechanism of action is based on damage to the cell wall of microorganisms, entry into the cell and disruption of its metabolism. They 
have bactericidal, virucidal and fungicidal action. Due to its positive properties, biodegradability, anticorrosiveness, cleaning and deodorizing ability, microbicidal action, DeSu preparations are successfully used in disinfection (Anon (1), Papić, 2015). In beekeeping, a combination of physical and chemical methods is successfully used for disinfection. Cooking tools and utensils in hot water with the addition of $1-2 \%$ crystal soda (sodium carbonate, $\mathrm{Na}_{2} \mathrm{CO}_{3}$ ) or the addition of $3 \% \mathrm{NaOH}$ is an effective method of disinfection.

The effects of chemical disinfectants on different groups of microorganisms are shown in Table 1 .

Table 1. Effects of chemical disinfectants on different groups of microorganisms (Titera, 2009, Žarković, 1971).

\begin{tabular}{|c|c|c|c|c|c|}
\hline \multirow{2}{*}{ Disinfectant } & \multicolumn{4}{|c|}{ Effect on microorganisms } & \\
\hline & Bacteria & Spore & Fungi & Viruses & Application \\
\hline $\begin{array}{l}\text { Oxidizing agents } \\
\text { (hydrogen peroxide) }\end{array}$ & Bactericid & Sporocid & Fungicide & Virucid & $\begin{array}{l}\text { Skin, mucous membranes, } \\
\text { surfaces, tools, instruments }\end{array}$ \\
\hline $\begin{array}{l}\text { Halogens } \\
\text { (Chlorine, iodine } \\
\text { and their } \\
\text { compounds) }\end{array}$ & Bactericid & Sporocid & Fungicide & Virucid & $\begin{array}{l}\text { Chlorine: surfaces, water } \\
\text { Iodine: skin, mucous membranes }\end{array}$ \\
\hline $\begin{array}{l}\text { Alcohols (ethyl } \\
\text { alcohol, isopropyl } \\
\text { alcohol) }\end{array}$ & Bactericid & No effect & Fungicide & Virucid & $\begin{array}{l}\text { Skin, mucous membranes, } \\
\text { surfaces, instruments }\end{array}$ \\
\hline $\begin{array}{l}\text { Aldehydes } \\
\text { (glutaraldehyde, } \\
\text { formaldehyde) }\end{array}$ & Bactericid & $\begin{array}{l}\text { Slightly } \\
\text { sporocidal }\end{array}$ & Fungicide & Virucid & Surfaces, instruments \\
\hline Phenols & $\begin{array}{l}\text { Bactericid } \\
\text { Bacteriostatic }\end{array}$ & No effect & Fungicid & Virucid & $\begin{array}{l}\text { Skin, mucous membranes, } \\
\text { surfaces, tools, instruments }\end{array}$ \\
\hline Ethylene oxide & Bactericid & Sporocidal & Fungicid & Virucid & $\begin{array}{l}\text { Surfaces, instruments, tools, } \\
\text { thermo-stable drugs, food }\end{array}$ \\
\hline Detergents & Bactericid & No effect & Fungistatic & No effect & $\begin{array}{l}\text { Cleaning of metal and wooden } \\
\text { surfaces, washing and cleaning of } \\
\text { packaging, washing dishes } \\
\text { Skin, mucous membranes }\end{array}$ \\
\hline $\begin{array}{l}\text { Biguanide } \\
\text { (chlorhexidine) }\end{array}$ & Bacteriostatic & $\begin{array}{l}\text { Biguanide } \\
\text { (chlorhexidine) }\end{array}$ & Fungistatic & $\begin{array}{l}\text { Virostatic } \\
\text { (act on } \\
\text { enveloped } \\
\text { viruses) }\end{array}$ & Skin, mucous membranes \\
\hline Inorganic acids & Bactericid & Sporocid & Fungicid & Virucid & $\begin{array}{l}\text { Disinfection of work surfaces, } \\
\text { corrosion resistant floors }\end{array}$ \\
\hline Organic acids & $\begin{array}{l}\text { Bactericid to some } \\
\text { bacteria }\end{array}$ & No effect & On some fungi & $\begin{array}{l}\text { On some } \\
\text { viruses }\end{array}$ & $\begin{array}{l}\text { Disinfection of work surfaces, } \\
\text { objects }\end{array}$ \\
\hline Bases & $\begin{array}{l}\text { Bactericid, } \\
\text { especially on gram } \\
\text { negative bacteria }\end{array}$ & $\begin{array}{l}\text { Sporocid in hot } \\
\text { solutions heated } \\
\text { to } 80-90^{\circ} \mathrm{C}\end{array}$ & Fungicid & Virucid & $\begin{array}{l}\text { Disinfection of work surfaces, } \\
\text { objects }\end{array}$ \\
\hline
\end{tabular}




\section{Table 2. shows the advantages and disadvantages of the most commonly used} disinfectants

Table 2. Advantages and disadvantages of the most commonly used disinfectants (Anon. 2003).

\begin{tabular}{|c|c|c|}
\hline Disinfectant & Advantages & Disadvantages \\
\hline Alcohols & $\begin{array}{l}\text { They act quickly, leave no residue, no } \\
\text { paint }\end{array}$ & $\begin{array}{l}\text { Volatile, can harden rubber objects, } \\
\text { dissolves glue, toxic }\end{array}$ \\
\hline $\begin{array}{l}\text { Chlorine and chlorine } \\
\text { compounds }\end{array}$ & Cheap, fast acting, easily available & $\begin{array}{l}\text { Corrosive to metals, inactivated by organic } \\
\text { matter, irritating to skin and mucous } \\
\text { membranes, should be used in well- } \\
\text { ventilated rooms, their shelf life is shortened } \\
\text { after dilution }\end{array}$ \\
\hline Formaldehyde & $\begin{array}{l}\text { Active in the presence of organic } \\
\text { matter }\end{array}$ & $\begin{array}{l}\text { Very limited use, Carcinogenic, poisonous, } \\
\text { very irritating, strong odor }\end{array}$ \\
\hline Glutaraldehyde & $\begin{array}{l}\text { Good disinfectant for equipment and } \\
\text { accessories that cannot be sterilized by } \\
\text { heat ( } 2 \% \text { solution), non-corrosive, } \\
\text { active in the presence of organic matter }\end{array}$ & $\begin{array}{l}\text { Extremely irritating and } \\
\text { toxic to skin and mucous membranes, } \\
\text { expensive, its shelf life is shortened after } \\
\text { dilution }\end{array}$ \\
\hline Hydrogen peroxide & $\begin{array}{l}\text { Strong oxidant, acts quickly, } \\
\text { decomposes quickly to water and } \\
\text { oxygen }\end{array}$ & $\begin{array}{l}\text { Can be corrosive to aluminum, copper, brass } \\
\text { or zinc, surface active - with limited } \\
\text { penetration }\end{array}$ \\
\hline Iodophors & They act quickly, relatively little toxic & $\begin{array}{l}\text { They are corrosive to metals, can damage } \\
\text { tissues, dyed fabrics, etc. }\end{array}$ \\
\hline Peracetic acid & $\begin{array}{l}\text { Suitable for items and utensils that } \\
\text { cannot be disinfected by heat. } \\
\text { Decomposes into water, oxygen, acetic } \\
\text { acid, hydrogen peroxide). It acts } \\
\text { quickly at low temperatures, it is active } \\
\text { in the presence of organic matter }\end{array}$ & It can be corrosive, unstable when diluted \\
\hline Phenols & $\begin{array}{l}\text { For disinfection of walls, floors, } \\
\text { objects, it is added to detergents and } \\
\text { thus washing and disinfection are } \\
\text { performed at the same time. }\end{array}$ & $\begin{array}{l}\text { It leaves residues on surfaces, it is not used } \\
\text { for surfaces that come in contact with food, } \\
\text { it can be absorbed by leather and rubber, } \\
\text { synthetic floors can become sticky if the use } \\
\text { of phenol is repeated. }\end{array}$ \\
\hline $\begin{array}{l}\text { Quaternary ammonium } \\
\text { compounds }\end{array}$ & $\begin{array}{l}\text { For cleaning floors, walls, objects, } \\
\text { usually do not irritate hands, usually } \\
\text { have detergent properties, are not } \\
\text { corrosive }\end{array}$ & $\begin{array}{l}\text { It is not used for disinfection of instruments } \\
\text { and tools, because it has a limited } \\
\text { antimicrobial effect }\end{array}$ \\
\hline Bases & $\begin{array}{l}\text { Easily soluble in water, easily reaches } \\
\text { microorganisms, decomposes organic } \\
\text { matter, efficiency increases to } 80-90^{\circ} \mathrm{C}\end{array}$ & $\begin{array}{l}\text { Corrosive, hard water reduces their } \\
\text { efficiency, in contact with air } \mathrm{NaOH} \text { is } \\
\text { inactivated, causes burns, eye damage }\end{array}$ \\
\hline Inorganic acids & $\begin{array}{l}\text { In a very short time, they break down } \\
\text { proteins and carbohydrates in the cell } \\
\text { of microorganisms. }\end{array}$ & $\begin{array}{l}\text { They irritate the skin and mucous } \\
\text { membranes, cause burns, are corrosive, so } \\
\text { they are rarely used }\end{array}$ \\
\hline Organic acids & $\begin{array}{l}\text { They are used as preservatives in the } \\
\text { food industry }\end{array}$ & $\begin{array}{l}\text { They do not have a strong bactericidal } \\
\text { effect, they are corrosive }\end{array}$ \\
\hline
\end{tabular}


Most of the bee viruses known so far belong to small, single-stranded RNA viruses that do not have a lipid envelope. They are called picorna viruses. These viruses are very resistant to disinfectants. Therefore, the main methods of disinfection are mechanical cleaning (removal and combustion of hive remains) and additional use of oxidizing agents for disinfection of equipment. Burning and annealing help to disinfect the equipment. The causative agents of American bee brood plague and European bee brood plague are considered to be the most important bacteria that cause diseases of honeybees. Both diseases are highly contagious. Generally, these bacteria can be destroyed by high temperatures. A 5\% solution of caustic soda acts against the spores of the American bee brood plague only if heated to $80^{\circ} \mathrm{C}$. In a mixture with sodium hypochlorite, caustic soda is effective even at room temperature. Vegetative forms and fungal spores are not as resistant as bacteria, so disinfection against them is more successful. Fungi can be killed by the action of high temperatures and most of the abovementioned chemical disinfectants (Plavša and Pavlović, 2017; Bojanić Rašović, 2018b, 2018c, 2018d; Bojanić Rašović, 2020a, 2020b; Ohashi et al. 2020; Nedialkov and Bižev, 1986; Rašić, 2018; Anon, 2020).

\section{CONCLUSIONS}

Disinfection is a very important measure that is implemented in order to prevent and suppress infectious diseases of bees and contamination of honey and other bee products with harmful microorganisms. The disinfection procedure is very complex, and its efficiency depends on a large number of factors. Due to the toxicity and other harmful effects of disinfectants, and often their insufficient efficiency, physical methods of disinfection should be applied whenever possible (application of high temperatures: dry heat - burning, annealing, ironing, tanning; moist heat (cooking, treatment with heated water steam under pressure), UV radiation). The chemical disinfectants that give the best results in beekeeping are chlorine preparations (sodium hypochlorite), caustic soda, alkaline salts $\left(\mathrm{Na}_{2} \mathrm{CO}_{3}\right)$ and oxidizing agents (peracetic acid). Chemical disinfection is often not successful, especially when it comes to the causative agents of American plague litters, which form very resistant spores. In that case, the only way is to burn the hives, so that they are not a source of infection.

\section{REFERENCES}

Anon. (1). Sredstva za dezinfekciju, Katalog sredstava za dezinfekciju, dezinsekciju, deratizaciju, Veterinarski zavod Subotica, p 1-24. http://www.victoriaoil.rs/sites/victoriaoil/files/katalozi/dezinfekcija.pdf $\quad$ (24.jun 2021.)

Anon. (2003): A Guide to Selection and Use of Disinfectants (2003). BC Centre for disease control, BCCDC Laboratory Services, 1-18.

Anon. (2014): "Hive cleaning and sterilization" (2014). National Bee Unit, APHA, National Agree-Food Innovation Campus p 1-12

Anon (2019): OIE - Terrestrial Animal Health Code - 28/06/2019 Chapter 4.14.- General recommendations on disinfection and disinsection, $\mathrm{p}$ 1-2. 
Anon (2020): Practices Guidelines on sustainable management of honeybee diseases in Europe, ERA-NETSUZAN, Istituto Zooprofilattico Sperimentale del Lazio e della Toscana, p 1-68.

Asaj A. (2000): Dezinfekcija, Medicinska naklada, Zagreb, 1-170).

Belojević G. (2013): Higijena, Univerzitet Crne Gore, Podgorica, p 1-279.

Bojanić Rašović M, Saičić I., Davidović V., Joksimović Todorović M, Relić R. (2016): Application of good manufacturing practice in beekeeping, Proceedings of the International Symposium on Animal Science, Faculty of Agriculture, University of Belgrade, Faculty of Agriculture, University of Novi Sad, 24 - 25. november, (ISAS) p 437-442.

Bojanić Rašović M. (2018a): Zoohigijena i preventiva bolesti, Univerzitet Crne Gore, Podgorica, p 1-480.

Bojanić Rašović M. (2018b): Američka kuga pčelinjeg legla, Pčelarstvo, Savez pčelarskih organizacija Crne Gore, No 210, p 12-15. (American bee brood plague, Beekeeping, Association of Beekeeping Organizations of Montenegro, No 210, p 12-15.)

Bojanić Rašović M. (2018c): Zdravstvena zaštita pčela u Crnoj Gori, Pčelarstvo, Savez pčelarskih organizacija Crne Gore: 14-15. (Bee health care in Montenegro. Beekeeping, Association of Beekeeping Organizations of Montenegro: 14-15

Bojanić Rašović M.(2018d). Evropska kuga pčelinjeg legla, Pčelarstvo, Savez pčelarskih organizacija Crne Gore, No 210, p 16-18.

Bojanić Rašović M., Davidović V., Joksimović-Todorović M. (2019a): Importance and measures of health protection of honeybees in Montenegro, Journal of Hygienic Engineering and Design, vol 29 p 50-54

Bojanić Rašović M. (2019b): Virusne bolesti pčela, Pčelarstvo, Savez pčelarskih organizacija Crne Gore, No 215, p 14-17. (Viral diseases of bees, Beekeeping, Association of Beekeeping Organizations of Montenegro).

Bojanić Rašović M. (2019c): Significance of the protection of honey bees from Braulosis (with a special focus on Montenegro). Agriculture and Forestry, 65 (2): 113-121.

Bojanić Rašović M. (2020a): Mikrobiologija, Univerzitet Crne Gore, Podgorica, p 1-411.

Bojanić Rašović M. (2020b): Značaj primjene dobre pčelarske prakse u proizvodnji meda i drugih pčelinjih proizvoda u Crnoj Gori, Pčelarstvo, Savez pčelarskih organizacija Crne Gore, p 1-28. (Importance of application of good beekeeping practice in the production of honey and other bee products in Montenegro, Beekeeping, Association of Beekeeping Organizations of Montenegro).

Bojanić Rašović M.(2021a): Značaj i metode dezinfekcije u stočarstvu (prvi dio), Pčelarstvo, Savez pčelarskih organizacija Crne Gore, No 238, p 22-25.

Bojanić Rašović M.(2021b): Značaj i metode dezinfekcije u stočarstvu (drugi dio), Pčelarstvo, Savez pčelarskih organizacija Crne Gore, No 239, p 20-23.

Bojanić Rašović M.(2021c): Značaj i metode dezinfekcije u stočarstvu (treći dio), Pčelarstvo, Savez pčelarskih organizacija Crne Gore, No 240, p 14-16.

Bojanić Rašović M.(2021d): Dezinfekcija u pčelarstvu (prvi dio), Pčelarstvo, Savez pčelarskih organizacija Crne Gore, No 241, p 20-26.

Buchrieser V., Miorini T. (2009): Osnovi čišćenja i dezinfekcije, Osnovna skripta za reprocesiranje medic. instrumenata i pribora, SUSID (Srpsko udruženje sterilizacije i dezinfekcije), p 1-19.

Nedialkov S., Bižev B. (1986): Praktično pčelarstvo, Nolit, Beograd, p 1-235. 
Ohashi I., Kato K., Okamoto M., Kobayashi S., takamatsu D. (2020): Microbicidal effects of slightly acidic hypochlorous acid water and weakly acidified chlorous acid water on foulbrood pathogens, J. Vet. Med. Sci. 82(3): 261-271, 2020, doi: 10.1292/jvms.19-0531

Papić S. (2015): Deterdženti, interna skripta, Fakultet kemijskog inženjerstva i tehnologije Sveučilišta u Zagrebu, Zagreb, 2015, 1-58).

Periškić M., Lolić M., Tucak I. (2013): Pčelarski leksikon, Osijek, p 1-68.

Plavša N., Pavlović I. (2017): Bolesti pčela, Univerzitet u Novom sadu, Poljoprivredni fakultet, Novi Sad, p 1-134

Radenković-Damnjanović B. (2010): Praktikum iz zoohigijene, Univerzitet u Beogradu, Fakultet veterinarske medicine, $\mathrm{p}$ 1-270

Rašić S. (2018): Dobra pčelarska praksa, SPOCG, Danilovgrad, p 1-122

Titera D. (2009): Hygiene in the apiary, A manual for hygienic beekeeping, BeeShop, The research project 'Bees in Europe and Sustainable Honey Production' Bri Dol, p 1-30

Vučemilo M. (2008): Higijena i bioekologija u peradarstvu, Veterinarski fakultet Sveučilišta u Zagrebu, Zagreb, p 1-276.

Vukićević Z., Hrgović N. (1988): Dezinfekcija u veterinarskoj medicini Savez veterinara i veterinarskih tehničara Jugoslaije, Beograd p 1-240

Žarković B. (1971): Dezinfekcija, dezinsekcija, deratizacija, Institut za stručno usavršavanje i specijalizaciju zdravstvenih radnika SRS, Beograd, p 1-347, https://www.tehnologijahrane.com/knjiga/dezinfekcija-dezinsekcija-deratizacija 